\title{
Application of nanoscale zero valent iron (NZVI) for groundwater remediation in Europe
}

\author{
Nicole C. Mueller • Jürgen Braun • Johannes Bruns • \\ Miroslav Černík • Peter Rissing • David Rickerby • \\ Bernd Nowack
}

Received: 23 March 2011 / Accepted: 22 July 2011 /Published online: 18 August 2011

(C) Springer-Verlag 2011

\begin{abstract}
Purpose Nanoscale zero valent iron (NZVI) is emerging as a new option for the treatment of contaminated soil and groundwater targeting mainly chlorinated organic contaminants (e.g., solvents, pesticides) and inorganic anions or metals. The purpose of this article is to give a short overview of the practical experience with NZVI applications in Europe and to present a comparison to the situation in the USA. Furthermore, the reasons for the difference in technology use are discussed.

Method The results in this article are based on an extensive literature review and structured discussions in an expert workshop with experts from Europe and the USA. The evaluation of the experiences was based on a SWOT (strength, weakness, opportunity, threat) analysis.
\end{abstract}

Responsible editor: Hailong Wang

N. C. Mueller $\cdot$ B. Nowack $(\bowtie)$

Technology and Society Laboratory, Empa, Swiss Federal

Laboratories for Materials Science and Technology,

Lerchenfeldstrasse 5,

9014 St Gallen, Switzerland

e-mail: nowack@empa.ch

N. C. Mueller

e-mail: nicole.mueller@empa.ch

J. Braun

Institut für Wasserbau, University of Stuttgart,

Pfaffenwaldring 61,

70569 Stuttgart, Germany

e-mail: juergen.braun@iws.uni-stuttgart.de

\section{J. Bruns}

Golder Associates GmbH,

Vorbruch 3,

29227 Celle, Germany

e-mail: johannes_bruns@golder.com
Result There are significant differences in the extent and type of technology used between NZVI applications in Europe and the USA. In Europe, only three full-scale remediations with NZVI have been carried out so far, while NZVI is an established treatment method in the USA. Bimetallic particles and emulsified NZVI, which are extensively used in the USA, have not yet been applied in Europe. Economic constraints and the precautionary attitude in Europe raise questions regarding whether NZVI is a cost-effective method for aquifer remediation. Challenges to the commercialization of NZVI include mainly nontechnical aspects such as the possibility of a public backlash, the fact that the technology is largely unknown to consultants, governments and site owners as well as the lack of long-term experiences.

\footnotetext{
M. Černík

Technical University of Liberec,

Studentská 2,

46117 Liberec, Czech Republic

e-mail: cernik@aquatest.cz

M. Černík

AQUATEST a.s.,

Geologická 4,

15200 Prague, Czech Republic

P. Rissing

Alenco Environmental Consult GmbH,

Ulmer Strasse 239,

70327 Stuttgart, Germany

e-mail: p.rissing@alenco-consult.com

D. Rickerby

Institute for Environment and Sustainability,

European Commission Joint Research Centre,

21027 Ispra, Italy

e-mail: david.rickerby@jrc.ec.europa.eu
} 
Conclusion Despite these concerns, the results of the current field applications with respect to contaminant reduction are promising, and no major adverse impacts on the environment have been reported so far. It is thus expected that these trials will contribute to promoting the technology in Europe.

Keywords Nanoscale zero valent iron (NZVI) . Remediation · Groundwater · Chlorinated hydrocarbons . European perspective

\section{Introduction}

In Europe, an estimated 20,000 polluted sites need to be remediated, and another 350,000 potentially contaminated sites have been identified by the European Environment Agency (Prokop et al. 2000). By comparison, in the USA, there are between 235,000 and 355,000 sites that require cleanup at an estimated cost of between $\$ 174$ and 253 billion ( $€ 115$ and 168 billion) (U.S. EPA 2005). Until 1992 , the predominant technology for addressing groundwater contamination was pump and treat (Karn et al. 2009; U.S. EPA 2005). As this type of ex situ treatment is very expensive and slow-the average pump and treat system operates for about 18 years (U.S. EPA 2001) - the number of public sites in the USA remediated by pump and treat has decreased to less than $20 \%$ in 2005 , and it is expected that ex situ remediation techniques will be phased out over the coming decade (Karn et al. 2009).

The first passive in situ treatment method introduced consisted of permeable reactive barriers (PRBs) using granular zero valent iron (ZVI, see Table 1 for abbreviations of particle types). Until now, granular ZVI has been used for many years at numerous sites in PRBs (Tratnyek and Johnson 2006), which are still considered the state-of-theart method. Metallic iron is very effective in transforming a wide variety of common contaminants such as chlorinated methanes, brominated methanes, trihalomethanes, chlorinated ethenes, chlorinates benzenes, other polychlorinated hydrocarbon pesticides, and dyes into less toxic compounds (Zhang 2003). In a reductive environment, chlorinated compounds are partially or totally dechlorinated to ethene and chloride. The reaction pathways have been extensively described in the literature (Dries et al. 2005; Klimkova et al. 2008; Müller et al. 2006; Schrick et al. 2002; Song and Carraway 2005; Zhang 2003). ZVI can not only reduce organic contaminants but also the inorganic anions such as nitrate which is reduced to ammonia (Liou et al. 2006; Sohn et al. 2006), perchlorate (plus chlorate or chlorite) which is reduced to chloride (Cao et al. 2005), selenate (Mondal et al. 2004), arsenate (Jegadeesan et al. 2005; Kanel et al. 2006), arsenite (Kanel et al. 2005), and chromate (Manning et al. 2007; Ponder et al. 2000). ZVI is also efficient in removing dissolved metals from solution, e.g., $\mathrm{Pb}$ and $\mathrm{Ni}$ (Li et al. 2006; Ponder et al. 2000). The major drawback, however, is that PRBs can only address contaminant plumes that flow through the barrier and hence they do not contribute to the active removal of the source. This has a direct impact on the duration of the remediation and the availability of the land for resale or reuse.

Nanoscale iron particles are- based on the large specific surface area-significantly more reactive than conventional ZVI and are to some extent able to migrate below ground,

Table 1 NZVI modifications and types used for soil and groundwater remediation

\begin{tabular}{|c|c|c|}
\hline Abbreviation & Description & Characteristics (Mueller and Nowack 2010) \\
\hline ZVI & Zero valent iron & Microscale \\
\hline NZVI & $\begin{array}{l}\text { Nanoscale zero valent iron (surface modified, e.g., with } \\
\text { inhicor-T, starch, carboxymethylene cellulose, } \\
\text { polyacrylic acid, cellulose, Tween } 60 \text { or } 80 \text { ) }\end{array}$ & $\begin{array}{l}\text { Surface modification aims to increase mobility in the } \\
\text { ground }\end{array}$ \\
\hline BNZVI & $\begin{array}{l}\text { Bimetallic NZVI (NZVI combined with a metal catalyst } \\
\text { such as } \mathrm{Ni}, \mathrm{Pd}, \mathrm{Pt}, \mathrm{Cu}, \mathrm{Ag} \text { ) }\end{array}$ & $\begin{array}{l}\text { BNZVI has a higher reaction rate than NZVI but } \\
\text { consequently a shorter lifetime }\end{array}$ \\
\hline c-NZVI & $\begin{array}{l}\text { NZVI on carbon support (NZVI combined with active } \\
\text { carbon platelets of } 50-200 \mathrm{~nm} \text { diameter) }\end{array}$ & $\begin{array}{l}\text { c-NZVI may be used to enhance the NZVI distribution } \\
\text { in contaminated aquifers (no field tests carried out yet) }\end{array}$ \\
\hline ENZVI & $\begin{array}{l}\text { Emulsified NZVI [NZVI core in water coated by } \\
\text { food-grade surfactants and biodegradable vegetable } \\
\text { oil which form an oil-liquid membrane } \\
\text { (about } 15 \mu \mathrm{m} \text { in diameter)] }\end{array}$ & $\begin{array}{l}\text { ENZVI was designed for the in situ treatment of dense } \\
\text { non-aqueous phase liquids (DNAPLs). Due to the } \\
\text { hydrophobic coating, ENZVI can mix with organic } \\
\text { contaminants (Quinn et al. 2005) }\end{array}$ \\
\hline $\mathrm{Fe}(\mathrm{B})$ & $\begin{array}{l}\text { Amorphous type of NZVI made from borohydride } \\
\text { reduction of dissolved Fe(III) }\end{array}$ & \\
\hline NANOFER & $\begin{array}{l}\text { NZVI produced from nanosized ferrihydrite by the } \\
\text { Czech company NANOIRON }\end{array}$ & \\
\hline RNIP & $\begin{array}{l}\text { Reactive nanoscale iron particle - a crystalline type } \\
\text { of nano-iron made by gas phase reduction of } \\
\text { FeOOH - produced by TODA Inc. Japan }\end{array}$ & \\
\hline
\end{tabular}


which allows active remediation of the contaminated plume and the source. These beneficial properties have led to a rapid increase of site remediation with NZVI in the USA while in Europe only a few full-scale applications have been carried out as yet. Other types of nanoparticles have also been tested for remediation purposes such as zeolites, calcium oxide, iron oxides, and (bi)metallic iron (Karn et al. 2009; Mueller and Nowack 2010; Theron et al. 2008; Zhang 2003). However, NZVI (nanoscale zero valent iron) is the most commonly used nanomaterial for soil and groundwater remediation at the present time (Karn et al. 2009). This article presents an overview of the use of NZVI for groundwater remediation from a European perspective and surveys pilot and full-scale remediations carried out so far. In addition, the concerns and limitations relating to the use of NZVI for groundwater remediation are discussed.

\section{Field applications of NZVI in Europe}

Karn et al. (2009) have compiled a comprehensive overview of some of the sites treated with NZVI. Most of those sites are located in the USA, and details can be viewed at the website of the Project on Emerging Nanotechnologies (Kuiken 2010). Comprehensive descriptions of case studies in the USA are found in the proceedings of an EPA Workshop (U.S. EPA 2005). In Europe, only a small number of pilot studies and a few full-scale remediations have been conducted (e.g., in the Czech Republic, Italy, and Germany).

\subsection{Pilot tests}

Before carrying out a full-scale application of NZVI, precise site investigations and pilot tests are needed, including the site hydrogeology as well as the geochemistry (Karn et al. 2009). The hydrogeology influences the transportability of the particles while the geochemistry indicates potential substances that NZVI could react with other than the target compounds and thus determines the lifetime of the reactive particles. Pilot tests are conducted to provide information on the amount of NZVI needed and possible unanticipated challenges. Table 2 summarizes the European pilot projects carried out with NZVI.

Table 2 Pilot tests with NZVI in Europe

\begin{tabular}{|c|c|c|c|c|c|c|c|c|}
\hline Site & Date & Contaminant & $\begin{array}{l}\text { Amount of } \\
\text { NZVI }\end{array}$ & $\begin{array}{l}\text { NVZI conc. } \\
\text { (slurry) }\end{array}$ & Particle type & $\begin{array}{l}\text { Injection } \\
\text { technique }\end{array}$ & Media & Source \\
\hline Uzin, CZ & 2009 & Cl-ethenes & $150 \mathrm{~kg}$ & $1-5 \mathrm{~g} / \mathrm{L}$ & Nanofer & Infiltration drain & $\begin{array}{l}\text { Low permeable } \\
\text { aquifer }\end{array}$ & (a) \\
\hline Rozmital, CZ & 2007-2009 & PCB & $150 \mathrm{~kg}$ & $1-5 \mathrm{~g} / \mathrm{L}$ & RNIP, Nanofer & Infiltration wells & Fractured bedrock & (a) \\
\hline Spolchemie, CZ & 2004,2009 & Cl-ethenes & $20 \mathrm{~kg}$ & $1-10 \mathrm{~g} / \mathrm{L}$ & $\mathrm{Fe}(\mathrm{B})$, Nanofer & Infiltration wells & Porous aquifer & (a), (b) \\
\hline Uhersky Brod, CZ & 2008 & Cl-ethenes & $50 \mathrm{~kg}$ & $1-5 \mathrm{~g} / \mathrm{L}$ & Nanofer & Infiltration wells & Porous aquifer & (a) \\
\hline Hluk, CZ & 2007,2008 & Cl-ethenes & $150 \mathrm{~kg}$ & $1-5 \mathrm{~g} / \mathrm{L}$ & RNIP, Nanofer & Infiltration wells & PRB filter & (a) \\
\hline Hannover, D & 2007 & $\begin{array}{l}\mathrm{CHC}^{\mathrm{a}}, \mathrm{BTEX}^{\mathrm{b}}, \\
\mathrm{HC}^{\mathrm{c}}\end{array}$ & $1 \mathrm{~kg}$ & n.a. & n.a. & Infiltration wells & Unspecified & (c) \\
\hline Asperg, D & 2006 & Cl-ethenes & $44 \mathrm{~kg}$ & $30 \mathrm{~g} / \mathrm{L}$ & RNIP & Sleeve pipe & Fractured rock & (d) \\
\hline Gaggenau, D & 2006 & PCE & $47 \mathrm{~kg}$ & $20 \mathrm{~g} / \mathrm{L}$ & RNIP & Sleeve pipe & Porous aquifer & (d) \\
\hline Permon, CZ & 2006 & $\mathrm{Cr}(\mathrm{VI})$ & $7 \mathrm{~kg}$ & $1-5 \mathrm{~g} / \mathrm{L}$ & RNIP & Infiltration wells & Fractured bedrock & (a) \\
\hline Kurivody, CZ & 2005,2006 & Cl-ethenes & $50 \mathrm{~kg}$ & $1-10 \mathrm{~g} / \mathrm{L}$ & $\mathrm{Fe}(\mathrm{B}), \mathrm{RNIP}$ & Infiltration wells & Fractured bedrock & (a), (b) \\
\hline Biella, I & 2005 & TCE, DCE & $10 \mathrm{~kg}$ & $1-10 \mathrm{~g} / \mathrm{L}$ & NZVI n.s. & Gravity infiltration & Porous aquifer & (b) \\
\hline Piestany, CZ & 2005 & Cl-ethenes & $20 \mathrm{~kg}$ & $1-5 \mathrm{~g} / \mathrm{L}$ & $\mathrm{Fe}(\mathrm{B})$ & Infiltration wells & $\begin{array}{l}\text { High permeable } \\
\text { aquifer }\end{array}$ & (a), (b) \\
\hline Schönebeck, D & 2005 & Vinyl chloride & $70 \mathrm{~kg}$ & $15 \mathrm{~g} / \mathrm{L}$ & RNIP & Push infiltration & Porous aquifer & (d) \\
\hline Thuringia, D & 2006 & $\begin{array}{l}\mathrm{CAH}^{\mathrm{d}}, \mathrm{Ni}, \mathrm{Cr}(\mathrm{VI}), \\
\text { nitrate }\end{array}$ & $120 \mathrm{~kg}$ & $10 \mathrm{~g} / \mathrm{L}$ & NZVI & Injection wells & Porous aquifer & (b) \\
\hline Brownfield, SK & n.a. & TCE, DCE & n.a. & n.a. & n.a. & n.a. & $\begin{array}{l}\text { Unconsolidated } \\
\text { sediments }\end{array}$ & (e) \\
\hline
\end{tabular}

n.a. information not available; n.s. not specified; (a) Aquatest, Czech Republic; (b) Golder Associates, Germany; (c) Bundesanstalt für Geowissenschaften und Rohstoffe, Germany (Houben and Kringel 2007); (d) Alenco GmbH, Germany; (e) Project on Emerging Nanotechnologies (Kuiken 2010)

${ }^{\text {a }}$ Chlorinated hydrocarbons

${ }^{\mathrm{b}}$ Aromatic hydrocarbons (benzol, toluol, ethylbenzol, and xylol)

${ }^{\mathrm{c}}$ Hydrocarbons

${ }^{\mathrm{d}}$ Chlorinated aliphatic hydrocarbons 
The results of these pilot tests differ significantly. At the Spolchemie site in the Czech Republic, contaminant concentrations remained low for 6 months after treatment, but increased thereafter to the original concentration. At the Kurivody site (also in the Czech Republic), the contaminant concentrations were reduced permanently by 75-95\%. PCE decreased from $2,500 \mu \mathrm{g} / \mathrm{L}$ to $500 \mu \mathrm{g} / \mathrm{L}$, trichloroethene (TCE) from $1,500 \mu \mathrm{g} / \mathrm{L}$ to $100 \mu \mathrm{g} / \mathrm{L}$, and dichloroethene (DCE) from $1,000 \mu \mathrm{g} / \mathrm{L}$ to $250 \mu \mathrm{g} / \mathrm{L}$ (Aquatest, personal communication). The remediation in Biella led to a reduction of the original total chlorinated solvent concentrations $(20,000-50,000 \mu \mathrm{g} / \mathrm{L})$ by about $20-50 \%$ within 1 month (Karn et al. 2009). The pilot test in Thuringia conducted by Golder Associates also showed significant reductions in contaminants (Golder Associates, personal communication).

\subsection{Full-scale applications}

\subsubsection{Bornheim, Germany}

Bornheim (Rhein-Sieg-Kreis, Germany) was the first contaminated site in Europe where NZVI was used for a full-scale remediation. The site was originally contaminated with several tons of PCE from an industrial laundry/dry cleaner. The pollutant had spread over an area of several square kilometers down to a depth of $20 \mathrm{~m}$. For 14 years, the groundwater had been treated by a combination of pump and treat, and soil vapor extraction. These measures removed around 5 tons of PCE at a cost of more than $€ 1$ million. It was estimated that remediation with these methods would need to continue for another 50 years to completely remove all contaminants. Details of the site can be found in Koschitzky et al. (2009).

The 1-2 tons of PCE left in the ground (sandy gravel) were then treated with NZVI (70 nm particle size, stabilized by polycarboxylic acid). One ton of NZVI (Toda RNIP, see Table 1 for all abbreviations of materials) and 2 tons of microsized ZVI were pumped into the ground within a single month (August 2007). The Fe suspension (about $90 \mathrm{~g} / \mathrm{L}: 30 \mathrm{~g} / \mathrm{L}$ NZVI and $60 \mathrm{~g} / \mathrm{L} 2.5 \mu \mathrm{m}$ iron) was introduced by sleeve-pipe injection (via plastic tubes with small holes at regular intervals) to $16-22 \mathrm{~m}$ depth. Ten wells were situated in the area with an injection radius of $2 \mathrm{~m}$ each.

The remediation was conducted by Alenco Environmental Consult $\mathrm{GmbH}$ at a cost of around $€ 290,000$ including monitoring (about $€ 366 / \mathrm{m}^{3}$ or $€ 290 / \mathrm{kg}$ PCE). The result of this project was an approximately $90 \%$ reduction of the concentration of total chlorinated compounds. No increase in the daughter products TCE and DCE was measured. Two years after the injection, no rebound has been observed and there is still a trend towards declining contaminant concentration. However, the success of the remediation cannot be unambiguously attributed to NZVI since both nanoscale and microscale particles were used.

\subsubsection{Horice, Czech Republic}

The full-scale application in Horice (Czech Republic) targeted an area of $120 \times 60 \mathrm{~m}$ contaminated with PCE, TCE, and DCE. The contamination was at a depth of $3-$ $10 \mathrm{~m}$, contaminant concentrations were up to $70 \mathrm{mg} / \mathrm{L}$, and the hydraulic conductivity was low (below $10^{-6} \mathrm{~m} / \mathrm{s}$ ). Details of the site are given by Černík (2010).

In the first stage (November 2008), 82 injection wells were bored and $300 \mathrm{~kg}$ of NZVI (NANOFER supplied by Nanoiron) were injected by a direct push method under a pressure of $0.8 \mathrm{MPa}$. Reductions of $60-75 \%(>90 \%$ in the diffuse plume) of the original contaminant concentration were achieved. In the second stage (November 2009), another $300 \mathrm{~kg}$ of NZVI were injected, and the decrease in concentration of chlorinated hydrocarbons continues (Fig. 1). The total costs for both treatments (including monitoring) were around $€ 300,000$ (Černík 2010).

\subsubsection{Pisecna, Czech Republic}

At the Pisecna site, the contaminated area was around $2,000 \mathrm{~m}^{2}$. Thirty wells were bored to treat about 1 ton of chlorinated ethenes at a depth of 20-35 m below the surface. In total, $2000 \mathrm{~kg}$ of NZVI were introduced in three steps: parallel pilot tests with RNIP and NANOFER and the subsequent two full-scale application using NANOFER only. The total costs were around $€ 360,000$.

The results of the pilot test showed a significant decrease in chlorinated hydrocarbon concentration (chlorinated ethenes and ethanes) of 40-80\%. Full-scale remediation began at the end of 2009 and followed one year later by the second injection. The final results are not yet available, but 3 months after the second injection the concentration of chlorinated hydrocarbons had dropped to about $20 \%$ of the initial values. Details of the site and preliminary results are reported by Černík (2010).

\section{European perspective on NZVI application}

\subsection{Media treated}

All field applications carried out in Europe so far targeted groundwater only. By comparison, in the USA, about half of the site remediations targeted groundwater alone. About one fifth treated groundwater and soil simultaneously and a small number of site remediations treated sands, clayey silts, or soils (Karn et al. 2009) (Fig. 2).

In Europe, NZVI was in most cases injected into high permeability aquifers (more than one third of sites), 25\% targeted fractured bedrock and only a few pilot projects were carried out in low permeability aquifers, unconsolidated sedi- 
Fig. 1 Monitoring of total chlorinated hydrocarbon concentrations in the full-scale remediation (Horice, Czech Republic). Top upper aquifer. Bottom lower aquifer. Left before remedial action. Right 1.5 years after the project start (6 months after second NZVI injection). The boxes and lines in the background indicate buildings. (CAquatest, Czech Republic
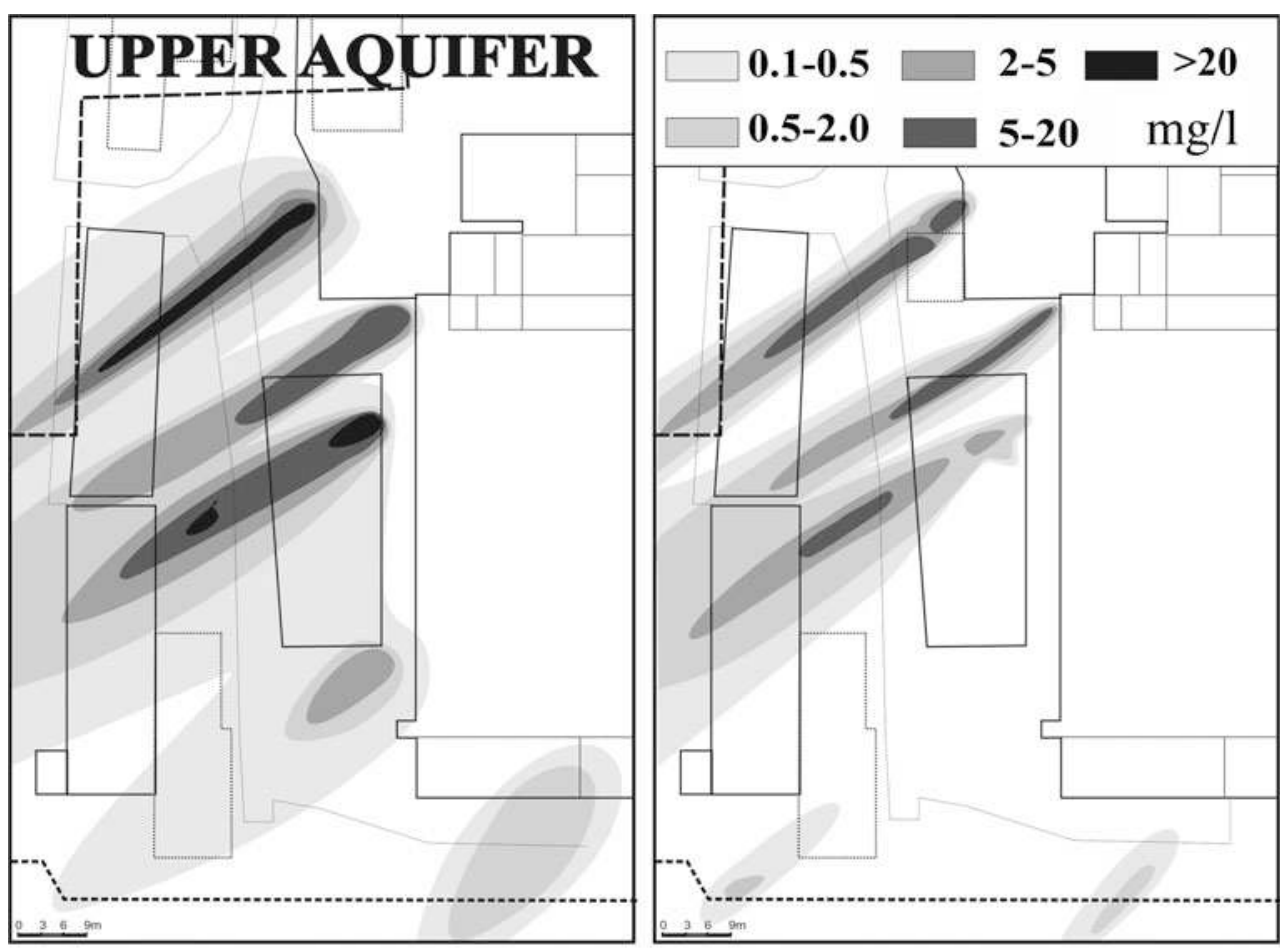

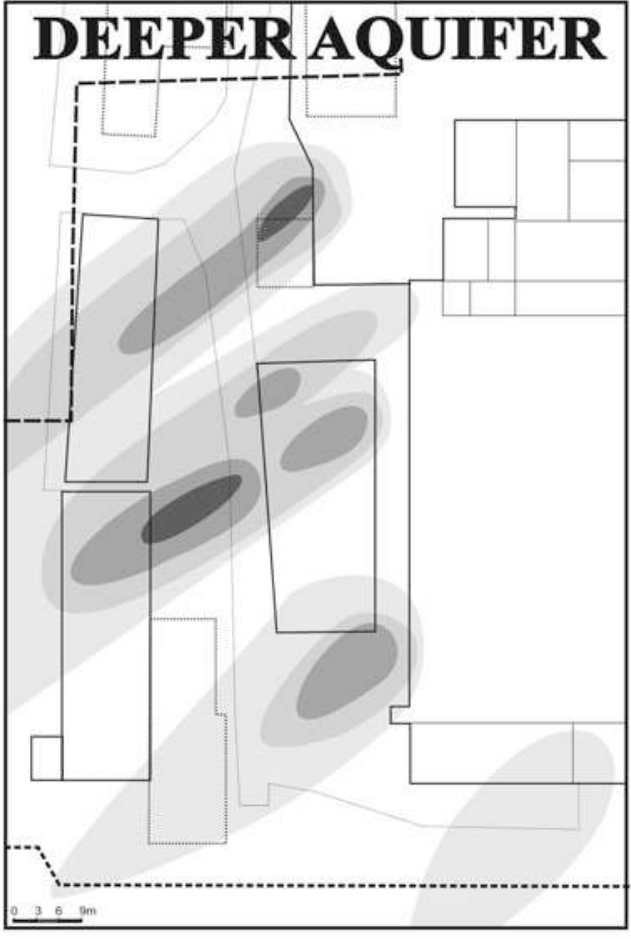

initial

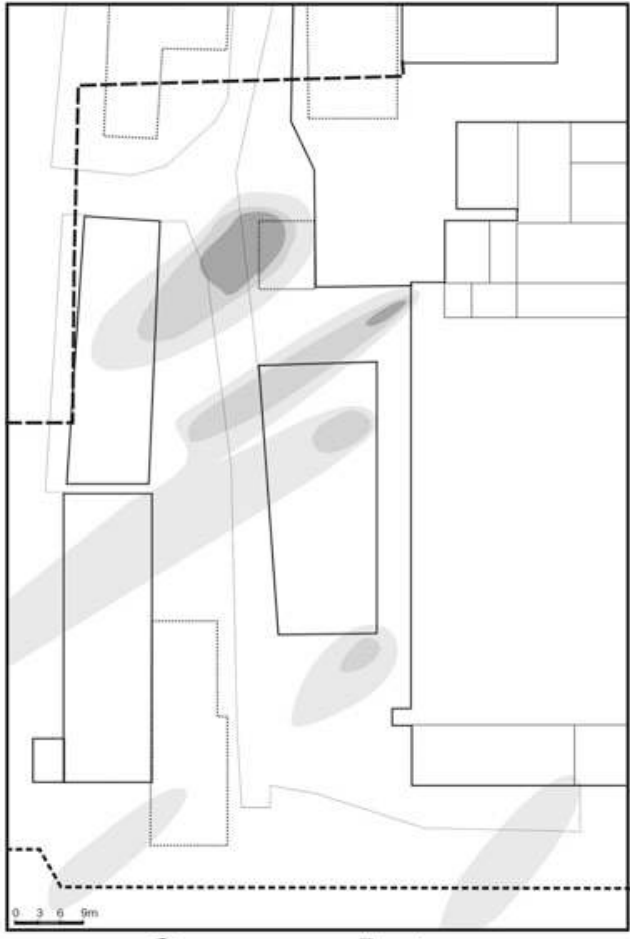

2 years later ments, or sandy gravel. For another $25 \%$ of the projects, the structure of the subsurface was not reported. Generally, it is agreed that remediation with NZVI in dense geological formations is less efficient and that unsaturated media are more difficult to treat. However, in these cases, hydraulic conductivity can be increased by fracturing and unsaturated zones can be flooded before or during the treatment.

\subsection{Target compounds}

The range of possible applications of NZVI is wide as it can not only effectively degrade organic contaminants but also immobilize inorganic anions such as arsenic or chromium and can even be used to recover/remove dissolved metals from solution (Müller et al. 2006; Nowack 2008; Parbs and 

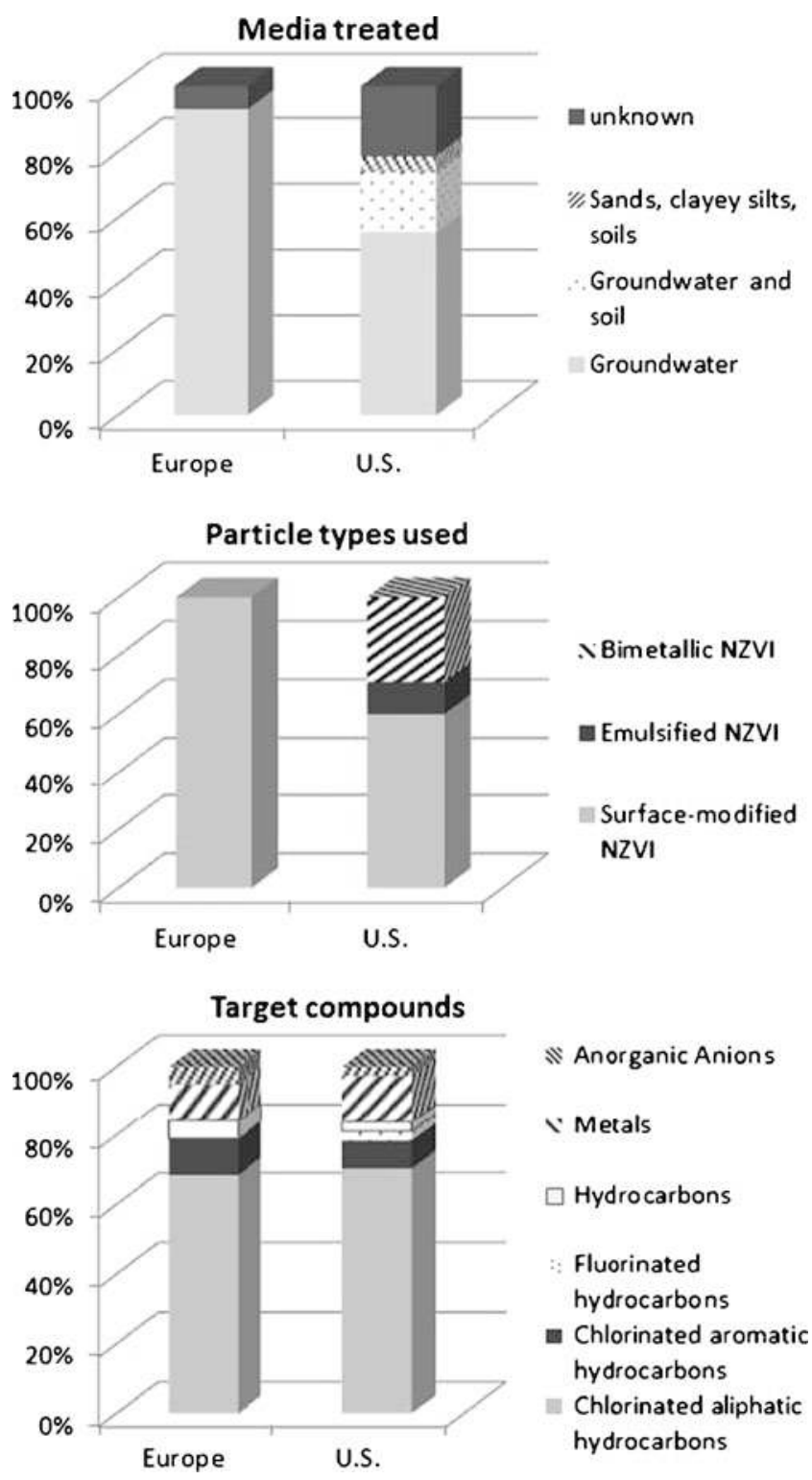

Fig. 2 Comparison of the media treated, particle types used, and the target compounds of NZVI applications in Europe and the USA. The graphs for Europe are based on the information in Table 2. The data used for the USA is extracted from the supplementary information of Karn et al. (2009). For the graph on the target compounds, remediation projects targeting different contaminant categories were counted in each category of which a contaminant was addressed during the treatment

Birke 2005; Rickerby and Morrison 2007). Zhang found NZVI to be effective also against PCB and organochlorine pesticides (Zhang 2003).

In Europe, most remedial actions with NZVI (70\%) addressed chlorinated ethenes (PCE, TCE, DCE) or other chlorinated hydrocarbons (e.g., PCB). A few pilot remediations $(20 \%)$ of other carbonaceous materials (BTEX, $\mathrm{HC}, \mathrm{VC}$ ) were additionally carried out. Ten percent of the remediations involved the immobilization of metals $(\mathrm{Cr}, \mathrm{Ni})$ and one pilot application also targeted nitrate (see Table 2).
For 15 field-scale applications in the USA, NZVI was in most cases used to treat a source zone of trichloroethanes (TCE) and daughter products, and some of the sites were contaminated with $\mathrm{Cr}(\mathrm{VI})$ (U.S. EPA 2005). The U.S. Navy promotes NZVI for the treatment of source zones contaminated with dense non-aqueous phase liquids (DNAPL) especially chlorinated alkenes such as PCE and TCE (U.S. Navy 2010). Golder Associates suggests NZVI for the treatment of chlorinated solvents, $\mathrm{Cr}(\mathrm{VI})$, and perchlorate, while Aquatest applies NZVI for both source and diffuse zones (Mueller and Nowack 2010). See Fig. 2 for the comparison of the targeted contaminants in Europe and the USA.

\subsection{Injection technology}

NZVI injection can be accomplished with several different methods (U.S. Navy 2010). The U.S. EPA (2005) has analyzed 15 field-scale applications of NZVI or bimetallic nanoscale iron. In a majority of these field applications, NZVI was applied by gravity-feed or low pressure injection. A similar situation is found in Europe: of 14 sites where data on the injection technology was available, nine used infiltration or gravity feed, three used sleeve-pipe injections, and two a direct push method (see Table 2).

There is no general agreement on the ideal particle concentration required in the slurry. Proposed concentrations by European experts vary between 1 and $2 \mathrm{~g} / \mathrm{L}$ and 10-30 g/L (Mueller and Nowack 2010). In about a third of the field applications in Europe an NZVI concentration in the slurry of up to $5 \mathrm{~g} / \mathrm{L}$ was used, in a further third up to $10 \mathrm{~g} / \mathrm{L}$, and in the remaining third concentrations of 15 $30 \mathrm{~g} / \mathrm{L}$ (see Table 2).

\subsection{Particle types used}

The greatest difference between Europe and the USA is the type of NZVI particle used. All remedial actions in Europe were carried out with standard NZVI [RNIP, NANOFER, or $\mathrm{Fe}(\mathrm{B})]$ while in the USA only $60 \%$ use standard NZVI. About $30 \%$ of the NZVI remediations in the USA use BNZVI and about 10\% are carried out with ENZVI (Karn et al. 2009). In Europe, there is no company working with ENZVI (see Fig. 2). The main reason is concern about the injectability of an emulsified suspension.

In Europe, no field application of BNZVI has been carried out so far. On one hand, the reactions with BNZVI are too fast and, due to the short lifetime of the particles in an aquifer, unsustainable for remediation (Mueller and Nowack 2010). On the other, there are concerns regarding the toxicity of the catalysts (e.g., $\mathrm{Ni}$ is considered to be a priority hazardous substance under the EU Water Framework Directive; Schrick et al. 2002). 


\section{Challenges of using NZVI}

Even though three companies in Europe are already pioneering the use of NZVI for the remediation of contaminated soils and groundwater, there are still some major issues to be resolved by researchers, environmental consultants, and also by governments.

\subsection{Technical challenges and toxicity}

Technical challenges of using NVZI in field applications include iron passivation through non-target reactions, the limited particle mobility, e.g., due to agglomeration, and the difficulties of scale-up from laboratory experiments to field tests (Mueller and Nowack 2010). The most promising conditions for remediation projects with NZVI are on sites where:

- Reasonably good injectability is assured;

- Porous ground allows for reasonable particle migration;

- A reductive environment limits non-target reactions;

- Chlorinated compounds are to be degraded or metals need to be immobilized.

Regarding the possible ecotoxicity of NZVI, not much is known yet. While some authors found NZVI to cause oxidative stress in cells (Auffan et al. 2008) or that oxidized NZVI could adsorb contaminants and serve as carrier (Gilbert et al. 2007), other authors assume that the reductive, anaerobic environment resulting from NZVI remediation may enhance the growth of bacteria which can further reduce the contaminant (Elliott and Zhang 2001).

It is evident that the direct application of nanoparticles for environmental remediation (such as NZVI for soil and groundwater remediation) is the largest point source for nanoparticle entry in the environment (Nowack and Bucheli 2007). As listed in Table 1, 7-150 kg of NZVI are typically introduced into the soil per pilot project, which is about one tenth at most of the amount used in full-scale remediations. In Europe, 1.3 tons was the largest amount applied on a single site. These numbers can be compared to the worldwide diffuse input of nanoparticles into the environment from other industrial and household sources that is estimated to be of the order of a 500 tons for $\mathrm{Ag}$ and carbon nanotubes per year (Gottschalk et al. 2009; Mueller and Nowack 2008).

\subsection{Regulations and acceptance by governments}

Governments need to balance the chances and risks of this new technology even though the data on (eco)toxicity available at the present time is not conclusive. There is no European country which has - to our knowledge-specific regulations on the use of nanomaterials for environmental remediation. The use of NZVI has thus to be evaluated by the governmental agencies by means of the current laws and regulations on chemical substances. In contrast to the USA, most agencies are-based on the precautionary principle - rather cautious, especially since there have been only a few full-scale remediations carried out in Europe so far. Environmental agencies in Italy, Germany, and the Czech Republic seem to be open-minded towards NZVI application as they have allowed pilot-scale or full-scale remediations.

Karn et al. (2009) have assessed different governmental position papers (e.g., from Royal Society, EC, Quebec Commission, EPA) and found that in general NZVI for remediation is looked on as more beneficial than harmful, but that it is the largest point source of environmental exposure and thus needs more research on its effects.

\subsection{Barriers to the market in Europe}

Besides the technical challenges and the need for regulation, there are additional barriers to the commercialization of the technology. The most prominent of these is the expense. Even though the overall costs of NZVI remediations were stated to be much lower than for other methods [PARS Environmental 2009 (last visit)], other aspects make the use of NZVI less attractive. In remediation with NZVI, all the costs arise within 1 or 2 years, while the costs of pump and treat are spread over 10-20 years (which may also be more favorable because of tax reductions). Other issues are the difficulty in getting approval by regulatory agencies and funding for research on the field scale, the lack of information about nano-remediation available to consultants and potential clients, and the lack of long-term experience with the technology (Mueller and Nowack 2010).

The German Federal Institute for Geosciences and Natural Resources, for example, has discontinued its activities in the field of remediation with NZVI in 2008 (Robert Kringel, personal communication). Despite the widespread application in the USA and the three successful projects in Europe, this institute has come to the conclusion that the technical difficulty of disseminating the iron below ground and the cost-benefit analysis indicate that NZVI technology is not yet ready for large-scale application. Based on its relatively broad applicability, it is estimated that at least 1,000 sites (about $5 \%$ of all contaminated sites) in the EU could be remediated with NZVI, but that the total market share of NZVI in Europe will not exceed 5-15\% of all contaminated sites (Mueller and Nowack 2010).

\section{Conclusions}

The NZVI remediation technologies applied in the USA and Europe are comparable regarding technical aspects 
such as injection method, particle concentration, and the media treated. However, remediation with NZVI in Europe is rare while it is widespread in the USA. The reason for this significant difference is mainly related to non-technical aspects. In the USA, authorities are more receptive towards innovative remediation solutions, among other reasons, because many of the sites are in remote areas with limited risk of human exposure. In Europe, however, many governmental bodies are reluctant to try new methods because of the precautionary principle. This difference of approach is also reflected in the particle types used. In the USA, $40 \%$ of all remediation projects are carried out with BNZVI; in Europe, only regular NZVI is applied because of concerns regarding the toxicity of the catalysts in BNZVI.

There is no agreement within the European expert community whether NZVI is a viable alternative for soil and groundwater remediation. Critics state that the competitiveness of NZVI for source treatment is in general very limited in comparison with ISCO (in situ chemical oxidation). The reasons are connected with the handling, mixing, and injection of the suspension, which is more expensive than the handling of a solution. It has been calculated that the price of NZVI must be less than $€ 10 / \mathrm{kg}$ to make it a feasible option (Mueller and Nowack 2010). However, there is general consensus that site characteristics determine the optimum method. The best opportunities for application of NZVI may be in cases where PCE is the sole contaminant, at low concentrations of reducible species (sulfate, nitrate, etc.), and in highly permeable aquifers.

The success of NZVI remediations in the USA and on some sites in Europe suggests that the scarcity of NZVI applications in Europe is not mainly due to technical reasons but rather based on societal acceptance and regulatory barriers.

Acknowledgments This paper is based on the results of a workshop financed by the EU-FP7 program "ObservatoryNano" (http://www. observatorynano.eu). Barbara Karn, U.S. EPA, United States, is thanked for useful discussions on the applications in the USA.

\section{References}

Auffan M, Achouak W, Rose J, Roncato M-A, Chaneac C, Waite DT, Masion A, Woicik JC, Wiesner MR, Bottero J-Y (2008) Relation between the redox state of iron-based nanoparticles and their cytotoxicity toward Escherichia coli. Environ Sci Technol 42:6730-6735

Cao J, Elliott D, Zhang W (2005) Perchlorate reduction by nanoscale iron particles. J Nanopart Res 7:499-506

Černík M (2010) Chemically supported in situ remedial technologies. VSCHT Praha, Praha, ISBN 978-80-7080-767-5 (in Czech)

Dries J, Bastiaens L, Springael D, Agathos S, Diels L (2005) Combined removal of chlorinated ethenes and heavy metals by zerovalent iron in batch and continuous flow column systems. Environ Sci Technol 39:8460-8465

Elliott D, Zhang W (2001) Field assessment of nanoscale biometallic particles for groundwater treatment. Environ Sci Technol 35:4922-4926

PARS Environmental (2009) An innovative remediation technology for soils and groundwater. Available at http://www.parsenviro. com/nanofeaw-1.html. Accessed 11 July 2011

Gilbert B, Lu G, Kim CS (2007) Stable cluster formation in aqueous suspensions of iron oxyhydroxide nanoparticles. J Colloid Interface Sci 313:152-159

Gottschalk F, Sonderer T, Scholz R, Nowack B (2009) Modeled environmental concentrations of engineered nanomaterials $\left(\mathrm{TiO}_{2}\right.$, $\mathrm{ZnO}, \mathrm{Ag}, \mathrm{CNT}$, fullerenes) for different regions. Environ Sci Technol 43:9216-9222

Houben G, Kringel R (2007) Remediation of contaminated groundwater with nanoparticles. DECHEMA-In situ Sanierung, Frankfurt am Main

Jegadeesan G, Mondal K, Lalvani S (2005) Arsenate remediation using nanosized modified zerovalent iron particles. Environ Prog 24:289-296

Kanel S, Manning B, Charlet L, Choi H (2005) Removal of arsenic (III) from groundwater by nanoscale zero-valent iron. Environ Sci Technol 39:1291-1298

Kanel S, Greneche J, Choi H (2006) Arsenic(V) removal from groundwater using nano scale zero-valent iron as a colloidal reactive barrier material. Environ Sci Technol 40:2045-2050

Karn B, Kuiken T, Otto M (2009) Nanotechnology and in situ remediation: a review of the benefits and potential risks. Environ Health Perspect 117:1823-1831

Klimkova S, Černík M, Lacinova L, Nosek J (2008) Application of nanoscale zero-valent iron for groundwater remediation: laboratory and pilot experiments. NANO Br Rep Rev 3:287-289

Koschitzky H-P, Trötschler O, Heitmann T, Klaas N (2009) Tracer experiment to determine the groundwater flow between the injection site and the CMT-measuring point at the former industrial laundry Ferster in Bornheim-Roisdorf: technical report nr. VEG39, 2009/11. Institut für Wasserbau, Universität Stuttgart (in German)

Kuiken T (2010) Cleaning up contaminated waste sites: is nanotechnology the answer? Nano Today 5:6-8. Available at http://www. nanotechproject.org/inventories/remediation_map. Accessed 11 July 2011

Li XQ, Elliott DW, W-Q Z (2006) Zero-valent iron nanoparticles for abatement of environmental pollutants: materials and engineering aspects. Crit Rev Solid State Mater Sci 31:111-122

Liou Y, Lo S, Kuan W, Lin C, Weng S (2006) Effect of precursor concentration on the characteristics of nanoscale zerovalent iron and its reactivity of nitrate. Water Res 40:2485-2492

Manning B, Kiser J, Kwon H (2007) Spectroscopic investigation of Cr (III)- and $\mathrm{Cr}(\mathrm{VI})$-treated nanoscale zerovalent iron. Environ Sci Technol 4:586-592

Mondal K, Jegadeesan G, Lalvani S (2004) Removal of selenate by Fe and NiFe nanosized particles. Ind Eng Chem Res 43:4922-4934

Mueller NC, Nowack B (2008) Exposure modeling of engineered nanoparticles in the environment. Environ Sci Technol 42:44474453

Mueller NC, Nowack B (2010) Nano zero valent iron-THE solution for soil and groundwater remediation? ObservatoryNANO Report. Available at http://www.observatorynano.eu/project/filesystem/ files/nZVI_final_vsObservatory.pdf. Accessed 11 July 2011

Müller C, Löbel E, Rissing P (2006) Remediation with nano-ironstate of the technology. Altlasten Spektrum 2:75-83 (in German)

U.S. Navy (2010) Description of NZVI. Available at https://portal. navfac.navy.mil/portal/page/portal/navfac/navfac_ww_pp/ navfac_nfesc_pp/environmental/erb/nzvi. Accessed 11 July 2011 
Nowack B (2008) Pollution prevention and treatment using nanotechnology. In: Krug H (ed) Nanotechnology, vol 2, Environmental aspects. Wiley-VCS, Weinheim, pp 1-15

Nowack B, Bucheli TD (2007) Occurrence, behavior and effects of nanoparticles in the environment. Environ Pollut 150:5-22

Parbs A, Birke V (2005) State-of-the-art report and inventory on already demonstrated innovative remediation technologies, EuroDemo Report, deliverable reference no. D6.2 part 1. Available at http://www.eurodemo.info/project-information-2/. Accessed 11 July 2011

Ponder S, Darab J, Mallouk T (2000) Remediation of Cr(VI) and Pb (II) aqueous solutions using supported, nanoscale zero-valent iron. Environ Sci Technol 34:2564-2569

Prokop G, Schamann M, Edelgaard I (2000) Management of contaminated sites in Western Europe, Topic Report No. 13/199, European Environment Agency

Quinn J, Geiger C, Clausen C, Major D (2005) Field demonstration of DNAPL dehalogenation using emulsified zero-valent iron. Environ Sci Technol 39:1309-1318

Rickerby D, Morrison M (2007) Report from the Workshop on Nanotechnologies for Environmental Remediation, JRC Ispra. Available at http://www.nanowerk.com/nanotechnology/reports/ reportpdf/report101.pdf. Accessed 11 July 2011
Schrick B, Blough J, Jones A, Mallouk TE (2002) Hydrodechlorination of trichloroethylene to hydrocarbons using bimetallic nickeliron nanoparticles. Chem Mater 14:5140-5147

Sohn K, Kang S, Ahn S, Woo M, Yang S (2006) Fe(0) nanoparticles for nitrate reduction: stability, reactivity, and transformation. Environ Sci Technol 40:5514-5519

Song H, Carraway E (2005) Reduction of chlorinated ethanes by nanosized zero-valent iron: kinetics, pathways, and effects of reaction conditions. Environ Sci Technol 39:6237-6245

Theron J, Walker JA, Cloete TE (2008) Nanotechnology and water treatment: applications and emerging opportunities. Crit Rev Microbiol 34:43-69

Tratnyek PG, Johnson RL (2006) Nanotechnologies for environmental cleanup. Nano Today 1:44-48

U.S. EPA (2001) Cost analysis for selected groundwater cleanup projects: pump and treat systems and permeable reactive barriers, Report 542-R-00-013. U.S. EPA, Washington DC

U.S. EPA (2005) U.S. EPA Workshop on Nanotechnology for Site Remediation, Washington, DC. Available at http://epa.gov/ncer/ publications/workshop/pdf/10_20_05_nanosummary.pdf. Accessed 11 July 2011

Zhang W (2003) Nanoscale iron particles for environmental remediation: an overview. J Nanopart Res 5:323-332 